\title{
Grains, whole flour, white flour, and some final goods: an elemental comparison
}

\author{
Kathrin Ertl $^{1} \cdot$ Walter Goessler ${ }^{1}$
}

Received: 23 March 2018 / Revised: 28 May 2018 / Accepted: 14 July 2018 / Published online: 6 August 2018

(c) The Author(s) 2018

\begin{abstract}
Concentrations of 27 elements (B, Na, Mg, Al, P, S, K, Ca, V, Cr, Mn, Fe, Co, Ni, Cu, Zn, As, Se, Rb, Sr, Mo, Cd, Sb, Ba, $\mathrm{Hg}, \mathrm{Pb}$, and $\mathrm{U}$ ) in grain, flour, different bread and pasta samples, all bought in Austria, were determined with an inductively coupled plasma mass spectrometer. In total, we have investigated 73 grain and flour samples, including rye (Secale cereale), spelt (Triticum spelta) and wheat (Triticum aestivum), and additional 54 bread samples and 21 pasta samples. All investigated samples were within legal limits and show no health risk with respect to metal contamination. Furthermore, the importance of whole flour over white flour in bread and pasta to meet the daily requirements with respect to major and trace elements is demonstrated.
\end{abstract}

Keywords Grain · Flour · Bread · Pasta · Elemental composition

\section{Introduction}

In 2015, the typical Austrian consumed $\sim 89.3 \mathrm{~kg}$ of grains [1]. That is significantly more than the average $65.7 \mathrm{~kg} /$ year/ capita in Europe [2] and demonstrates the importance of grains in the Austrian diet. Soft wheat is per capita the main grain $(58.8 \mathrm{~kg})$, followed by maize and rye $(12.7$ and $9.3 \mathrm{~kg}$, respectively) [1]. The high wheat consumption is a result of the vast field of products containing wheat as main ingredient like bread, countless bakery products, pasta and its use for thickening gravy and sauces. Spelt is with less than $1 \mathrm{~kg} /$ capita/year mainly for bread production of interest.

From the large amount of consumed grains, only a small part can be attributed to whole grain products. However, it has to be stated that there is no consistent definition of whole grain products across Europe. The European Union agricultural legislation referred to whole grains as "grains from which only the part of the end has been removed, irrespective of characteristics produced at each stage of milling" [3]. Nevertheless, for Italy, mean whole grain intakes were published as $2.1 \mathrm{~g} /$ day in children and adolescents, whereas adults consume approximately $3.7 \mathrm{~g} / \mathrm{day}$, which means less

Walter Goessler

walter.goessler@uni-graz.at

1 Institute of Chemistry, University of Graz, Universitätsplatz 1/I, 8010 Graz, Austria than $1.5 \mathrm{~kg} /$ year [4]. For the French population, similar results were published. For whole grain consumers, $9.1 \mathrm{~g} /$ day for children and $14.4 \mathrm{~g}$ /day for adults were reported, but more than half of the respondents to the questionnaire explained to never consume any whole grain [5]. These values demonstrate rather low whole grain intakes, although whole flour products are more suitable to meet the daily requirement of several elements than white flour products. The Swedish National Food Agency for instance recommends a whole grain consumption of $70 \mathrm{~g} /$ day for women and $90 \mathrm{~g} /$ day for men [6]. A study from 2007 revealed that consumers regard cereal products as good for their health, but the awareness of whole grain products being healthier than white flour products varied between consumer groups [7]. There are enough data published referring to element concentrations in grains and flours, as shown in Results and discussion. Furthermore, gluten-free products, ancient crops as well as the physical and sensory characteristics of whole grain products have been investigated recently [8-13]. However, a comparison of the elemental composition of whole flour and white flour from spelt, rye, and wheat as well as their final goods at once has not been done.

To give meaning to determined element concentrations in different foodstuff, it is useful to compare them to published recommended dietary allowance (RDA) or adequate intake (AI) values $[14,15]$. RDA values express the average daily dietary intake level that is sufficient enough to meet nutrient 
requirements of 97-98\% of healthy people in particular life stages and gender groups. In case an RDA value cannot be determined, AI values are set. They are based on observed or experimentally determined approximations of nutrient intake by a group of healthy people, which are assumed adequate.

The aim of this work is to compare the elemental composition, including bulk elements, trace elements as well as heavy metals, of different grains as well as the final goods bread and pasta. To our knowledge, this is the first paper to compare and discuss the concentration of 27 elements in grains, whole flour, and flour from rye, spelt and wheat grown and processed in Austria. Furthermore, we want to highlight the importance of whole flour, in comparison with white flour, to meet RDA, or AI values for trace elements. This knowledge should further increase the awareness of the importance of whole flour products over white flour products. Therefore, concentrations of $\mathrm{B}, \mathrm{Na}, \mathrm{Mg}, \mathrm{Al}, \mathrm{P}, \mathrm{S}, \mathrm{K}$, $\mathrm{Ca}, \mathrm{V}, \mathrm{Cr}, \mathrm{Mn}, \mathrm{Fe}, \mathrm{Co}, \mathrm{Ni}, \mathrm{Cu}, \mathrm{Zn}, \mathrm{As}, \mathrm{Se}, \mathrm{Rb}, \mathrm{Sr}, \mathrm{Mo}, \mathrm{Cd}$, $\mathrm{Sb}, \mathrm{Ba}, \mathrm{Hg}, \mathrm{Pb}$, and $\mathrm{U}$ were determined and discussed.

\section{Materials and methods}

\section{Reagents and materials}

Ultrapure water, supplied by a Milli-Q purification system (Merck Millipore, Darmstadt, Germany) and nitric acid Rotipuran p.a. $\geq 65 \%$ (Carl Roth, Karlsruhe, Germany) further purified via a quartz sub boiling distillation (EMLS, Leutkirch, Germany) were used throughout. Calibration standards and internal standard solution were prepared via dilution from Single Element Standards for ICP (Carl Roth, Karlsruhe, Germany). The reference materials RM 8414 (NCR RM 8414-Bovine Muscle Powder, National Research Council Canada, Ottawa, Canada), RM 1568b (NIST SRM 1568b-Rice Flour, National Institute of Standards and Technology, Gaithersburg, USA) and SRM 1640a (NIST SRM 1640a-Trace Elements in Natural Water, National Institute of Standards and Technology, Gaithersburg, USA) as well as a round-robin wheat reference material ALVA-PA15/3 (ALVA-PA15/3, AGES, Linz, Austria) were used to ensure accuracy of the results.

\section{Samples}

All samples were bought in Austria. Their origin and the water content are listed in Table 1. "Wheat pasta coloured" puts all pasta samples together, where different powders have been added to change the colour of the noodles, e.g., spinach or basil for green and tomatoes or beetroot for different shades of red. For grain, flour samples and pasta samples between 0.5 and $1 \mathrm{~kg}$ depending on the packaging size were bought. Bread samples including different rolls and buns varied between 60 and $0.5 \mathrm{~kg}$.

\section{Sample preparation}

For each sample, a representative aliquot, for instance, for bread two slices approximately $1 \mathrm{~cm}$ thick, was taken. At least $50 \mathrm{~g}$ of each sample were freeze-dried for about 5 days (Christ Beta 2-16, LMC-1, Fa. CHRIST, Osterode, Germany). If required samples were further homogenized with a mortar and pestle and mineralized in a pressurized microwave-assisted acid digestion system (UltraCLAVE III, MLS GmbH, Leutkirch, Germany), flour samples were mineralized without prior drying. Therefore, each sample was weighed three times (about $0.5 \mathrm{~g}$ weighed to $0.1 \mathrm{mg}$ ) in a $12 \mathrm{~cm}^{3}$ Quartz tube and $5 \mathrm{~cm}^{3}$ of nitric acid were added. Thereafter, the tubes were placed in the autoclave pressurized with argon (40 bars) and heated according to the following program: ramp in $10 \mathrm{~min}$ to $75^{\circ} \mathrm{C} /$ in $15 \mathrm{~min}$ up to $150{ }^{\circ} \mathrm{C} /$ in $20 \mathrm{~min}$ up to $250{ }^{\circ} \mathrm{C} / 30 \mathrm{~min}$ at $250{ }^{\circ} \mathrm{C}$. After finishing the microwave heating, the solutions were transferred into $50 \mathrm{ml}$ Cellstar PP-Test tubes (Greiner Bio-One International AG, Kremsmünster, Austria) and filled to the mark with ultrapure water. In each run, at least three reference materials and three blanks were included. To obtain the flour samples water content, approximately $5 \mathrm{~g}$ flour were put into glass petri dishes and dried to constant weight in a drying oven (Heraeus T5050, Heraeus Holding GmbH, Hanau, Germany) at $80^{\circ} \mathrm{C}$.

\section{Element analysis}

Element analysis was carried out with an inductively coupled plasma mass spectrometer (ICPMS Agilent 8800, Agilent Technologies, Waldbronn, Germany). The following isotopes were used for determination: no-gas mode: ${ }^{11} \mathrm{~B}$, ${ }^{27} \mathrm{Al},{ }^{31} \mathrm{P},{ }^{34} \mathrm{~S},{ }^{98} \mathrm{Mo},{ }^{111} \mathrm{Cd},{ }^{121} \mathrm{Sb},{ }^{137} \mathrm{Ba},{ }^{201} \mathrm{Hg},{ }^{208} \mathrm{~Pb}$, and ${ }^{238} \mathrm{U}$; helium mode: ${ }^{23} \mathrm{Na},{ }^{24} \mathrm{Mg},{ }^{39} \mathrm{~K},{ }^{43} \mathrm{Ca},{ }^{51} \mathrm{~V},{ }^{52} \mathrm{Cr},{ }^{55} \mathrm{Mn}$, ${ }^{56} \mathrm{Fe},{ }^{59} \mathrm{Co},{ }^{60} \mathrm{Ni},{ }^{65} \mathrm{Cu},{ }^{66} \mathrm{Zn},{ }^{85} \mathrm{Rb}$, and ${ }^{86} \mathrm{Sr}$; hydrogen mode: ${ }^{78} \mathrm{Se}$; and oxygen mode: ${ }^{75 \rightarrow 91} \mathrm{As}$.

\section{Quality control}

To control instrument stability, a solution of ${ }^{9} \mathrm{Be},{ }^{74} \mathrm{Ge}$, ${ }^{115} \mathrm{In}$, and ${ }^{175} \mathrm{Lu}$ was continuously added online as internal standard. Furthermore, every 10th sample a control standard was measured. Analysis of the reference material RM 8414 "Bovine muscle powder", RM 1568b "Rice flour" and the round-robin wheat reference material ALVA-PA15/3 found all elements in good agreement with the given estimate and information values (see Table 2). 
Table 1 Analyzed grain samples and when needed flourtype number in parentheses, scientific name, origin ( $A T$ Austria, $D L$ Germany, IT Italy, $F R$ France), number of samples, and water content $[\%]$

\begin{tabular}{|c|c|c|c|c|}
\hline English name & Scientific name & Origin & $\mathrm{n}$ & $\begin{array}{l}\text { Water content [\%] } \\
\bar{x} \pm \sigma\end{array}$ \\
\hline Rye grain & Secale cereale & AT & 13 & $5.5 \pm 1.5$ \\
\hline Rye flour & & AT & 9 & $10 \pm 1$ \\
\hline Rye whole flour & & AT & 3 & $10 \pm 1$ \\
\hline Rye flour bread & & AT & 9 & $39 \pm 3$ \\
\hline Rye flour bread with seeds & & AT & 3 & $35 \pm 7$ \\
\hline Rye whole flour bread & & AT & 5 & $42 \pm 3$ \\
\hline Spelt grain & Triticum spelta & AT & 8 & $6.4 \pm 1.4$ \\
\hline Spelt flour & & AT & 3 & $11 \pm 1$ \\
\hline Spelt whole flour & & AT & 3 & $10 \pm 1$ \\
\hline Spelt whole flour bread & & AT & 7 & $35 \pm 6$ \\
\hline Wheat grain & Triticum aestivum & AT & 9 & $6.2 \pm 1.1$ \\
\hline Wheat flour $\left(480^{\mathrm{a}}\right)$ & & AT & 14 & $11 \pm 1$ \\
\hline Wheat flour $\left(700^{\mathrm{a}}\right)$ & & AT & 6 & $11 \pm 1$ \\
\hline Wheat whole flour & & AT & 5 & $10 \pm 1$ \\
\hline Wheat flour-pretzel stick & & AT, DL & 6 & $30 \pm 1$ \\
\hline Wheat flour bread & & AT, DL, FR & 11 & $31 \pm 4$ \\
\hline Wheat flour bread with seeds & & AT & 13 & $31 \pm 4$ \\
\hline Wheat pasta & Triticum durum & AT, DL, IT & 7 & $7.0 \pm 0.4$ \\
\hline Wheat pasta coloured & & AT, DL, IT & 10 & $7.0 \pm 0.4$ \\
\hline Whole wheat pasta & & IT & 4 & $8.5 \pm 0.4$ \\
\hline
\end{tabular}

${ }^{\mathrm{a}}$ German and Austrian flour-type numbers indicate the amount of ash (in $\mathrm{mg}$ ) obtained from $100 \mathrm{~g}$ of the dry mass of the flour

\section{Statistical evaluation}

For the different grain and flour types as well as bread and pasta samples, mean values and standard deviations were calculated (see Tables 3, 4). Because of the limited sample number further, statistical analysis was refrained. The element concentrations in $100 \mathrm{~g}$ of different flour types, bread samples, and uncooked pasta samples were compared to published recommended dietary allowance (RDA) or adequate intake (AI) values $[14,15]$ to estimate the approximate contribution for the daily requirement (see Table 5). RDAs and AIs are sex and age dependent. For calculations, values for males/females from the group of 31-50 years were used. Quotients shown in Fig. 1 were calculated as element concentration whole flour wet mass divided by element concentration white flour wet mass. In the case of bread, products out of spelt whole flour and wheat flour were compared.

Limits of detection (LOD) were calculated as the signal response of the blank solutions plus three times the standard deviation of the blank signals divided by the slope of the calibration. These concentrations were multiplied with the sample dilution. Values below $1 \mu \mathrm{g} / \mathrm{kg}$ are all expressed as $1 \mu \mathrm{g} / \mathrm{kg}$.

Unless otherwise stated all concentrations presented in Results and discussion as well as values presented in Tables 2, 3 and 4 are expressed on a dry mass basis.

\section{Results and discussion}

\section{$\mathrm{Na}, \mathrm{Mg}, \mathrm{P}, \mathrm{S}, \mathrm{K}$, and $\mathrm{Ca}$}

Sodium concentrations in all investigated grain and flour samples are quite low with five samples, even below the limit of detection of $1 \mathrm{mg} / \mathrm{kg}$. The highest observed concentration $9.5 \mathrm{mg} / \mathrm{kg}$ is still rather low, which would make grains dietary favourable, when not considering the addition of salt during further processing. Higher sodium concentrations in grains from $8 \mathrm{mg} / \mathrm{kg}$ up to $37.1 \mathrm{mg} / \mathrm{kg}$ were reported in several papers [16-18]. Whereas also all pasta samples did not exceed $0.32 \mathrm{~g} / \mathrm{kg}$ sodium, bread samples showed high sodium concentrations up to $11 \mathrm{~g} / \mathrm{kg}$, which is related to the addition of salt during production.

Magnesium concentrations range from $0.15 \mathrm{~g} / \mathrm{kg}$ up to $1.7 \mathrm{~g} / \mathrm{kg}$ in grain and flour samples. Very similar values are reported in the literature with concentrations between 0.35 and $1.4 \mathrm{~g} / \mathrm{kg}$ in wheat and wheat flour [17, 19-21]. For rye flour $1.0 \mathrm{~g} / \mathrm{kg}$ and for spelt $1.5 \mathrm{~g} / \mathrm{kg}$ were reported by Podio et al. [17] and Suchowilska et al. [18], respectively. Bread samples have comparable concentrations between 0.19 and $1.7 \mathrm{~g} / \mathrm{kg}$ as the main flour type used. To meet the daily magnesium requirements, adults should consume between 300 and $420 \mathrm{mg} /$ day depending on age and sex [14], which can be met by the consumption of 
Table 2 Best estimate and information (*) values in RM 8414 "Bovine muscle powder" and given values for the reference material RM1568b "rice flour" and the wheat flour round-robin reference material ALVA-PA15/3

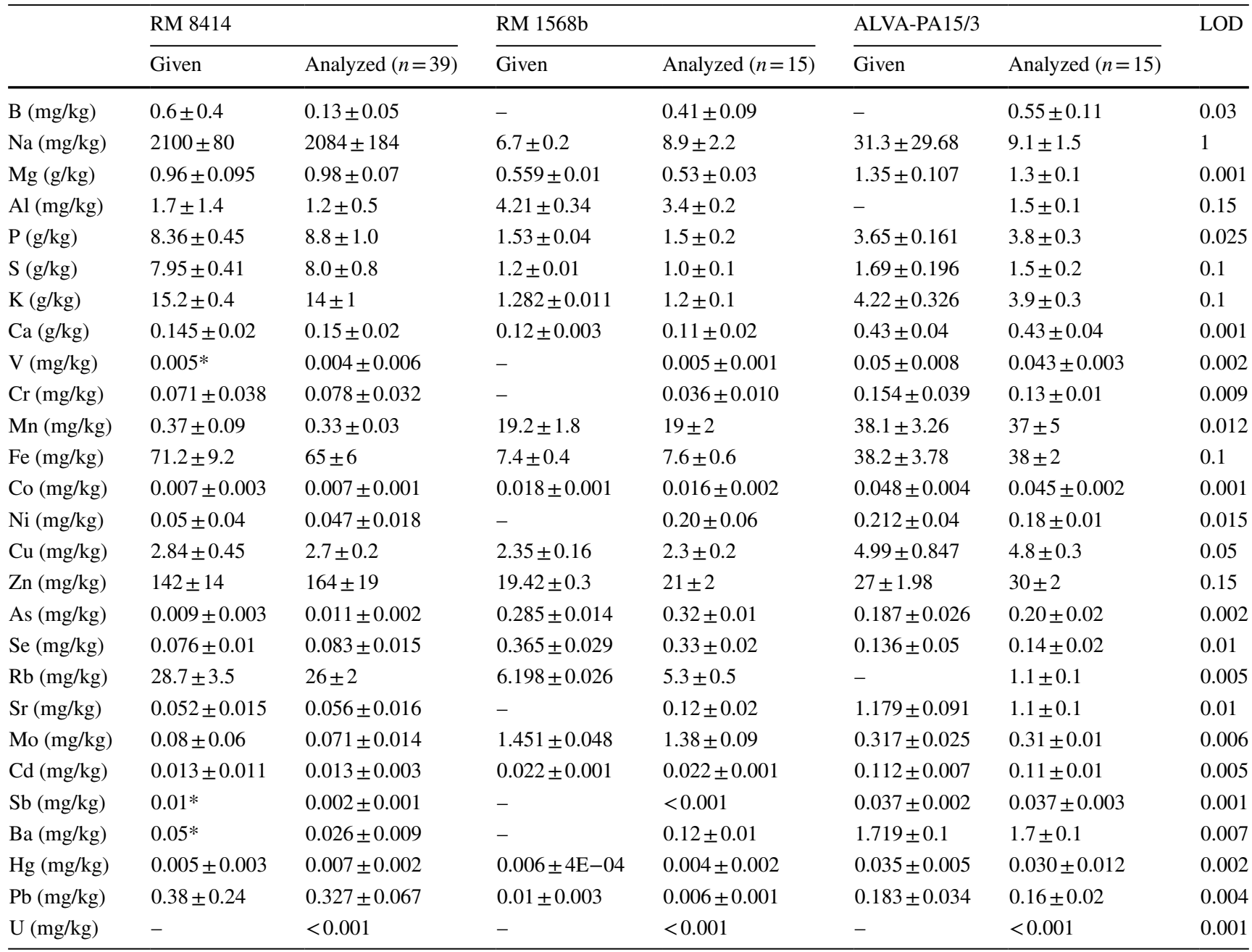

approximately $0.38-0.53 \mathrm{~kg}$ of whole spelt bread compared to $1.3-1.8 \mathrm{~kg}$ of pretzel sticks.

Phosphorus ranges from 2.9 to $5.4 \mathrm{~g} / \mathrm{kg}$ and is far more present in grain and whole flour samples, with spelt showing the highest concentrations, than in white flour samples with a range between 0.76 and $2.8 \mathrm{~g} / \mathrm{kg}$. In the literature, concentrations between 1.4 and $5.4 \mathrm{~g} / \mathrm{kg}$ in various grain samples were reported $[18,20,21]$. In pasta samples, phosphorus concentration is twice as high for whole flour pasta than for white flour pasta. The difference between whole flour and white flour is not so evident, although still present when examining bread products. In the case of bread products the consumption of 230-600 g of whole spelt flour bread is enough to meet the daily requirement, whereas $410-1000 \mathrm{~g}$ of wheat flour bread would be needed.

Sulfur shows, in contrast to phosphorus, less difference between flour and whole flour concentrations. Overall, the concentrations range between 0.78 and $2.1 \mathrm{~g} / \mathrm{kg}$ for grain and flour samples and between 0.88 and $1.9 \mathrm{~g} / \mathrm{kg}$ for bread and pasta samples. Concentrations for total sulfur are scarce in literature. Suchowilska et al. reported a sulfur value of $1.8 \mathrm{~g} / \mathrm{kg}$ for spelt, which is in good agreement with results obtained in this study [18].

Potassium, similar to phosphorus, shows with $3.0-4.8 \mathrm{~g} /$ $\mathrm{kg}$ for whole flour much higher concentrations than flour samples with $0.76-3.2 \mathrm{~g} / \mathrm{kg}$. All flour mean concentrations show a pronounced difference to the corresponding whole flour mean concentrations. Literature data for wheat flour were reported from $1.7 \mathrm{~g} / \mathrm{kg}$ up to $4.9 \mathrm{~g} / \mathrm{kg}[17,18,20-22]$. In addition, bread and pasta with overall range from 1.0 to 5.5 and 1.8 to $4.4 \mathrm{~g} / \mathrm{kg}$, respectively, and show clear differences between whole flour and flour products.

Calcium is together with magnesium, phosphorus, sulfur, and potassium one of the main elements present in grains. The overall range from 0.13 to $0.46 \mathrm{~g} / \mathrm{kg}$ for grains and flours is in good agreement with published results ranging between 0.14 and $0.65 \mathrm{~g} / \mathrm{kg}$ [17-22]. $100 \mathrm{~g}$ of bread can provide between 2 and $4 \%$ of the daily requirement depending 


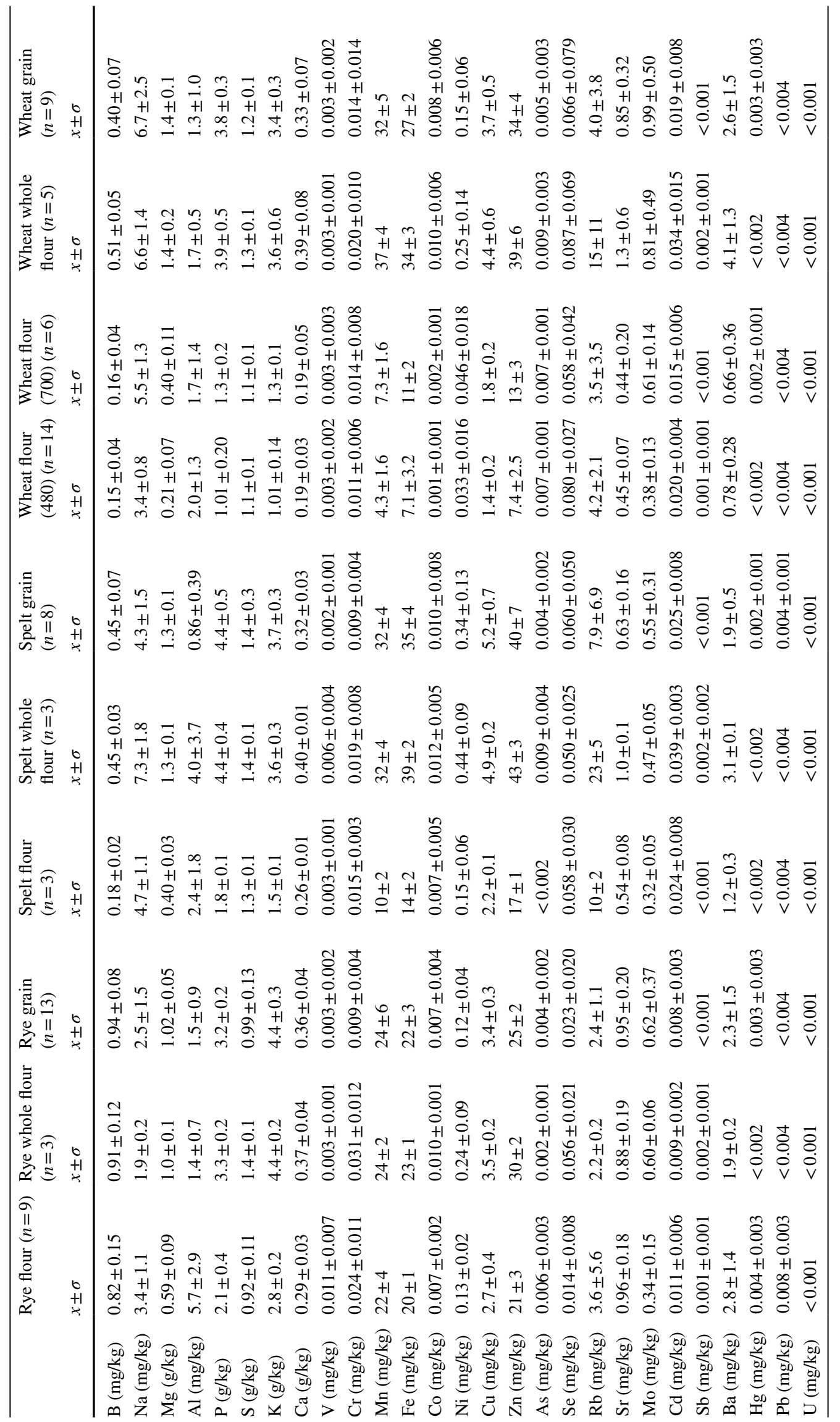




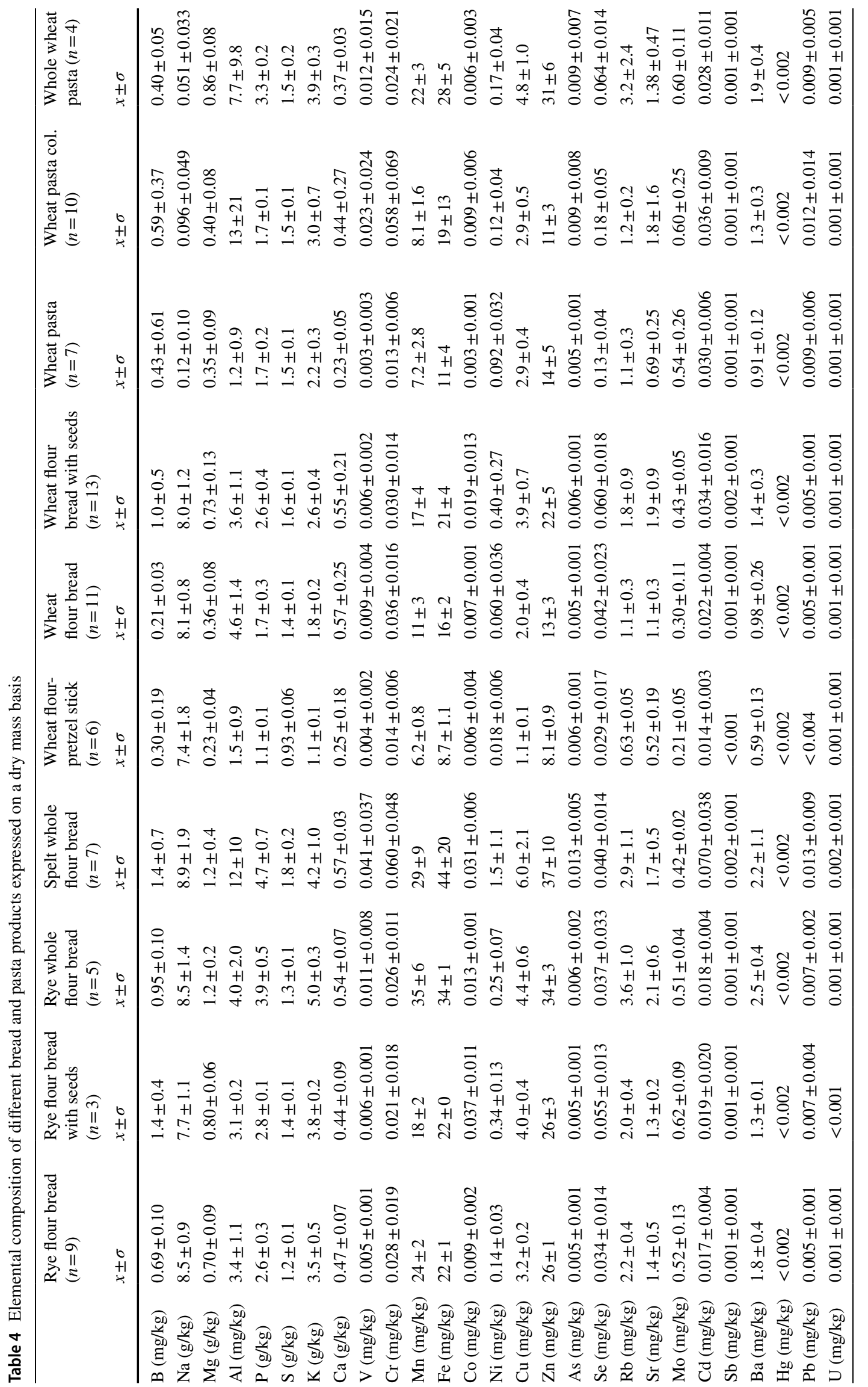


Table 5 Percentage of the daily requirement (RDA or AI for male/female between 31 and 50 years) that can be reached through the consumption of $100 \mathrm{~g}$ of different flour types, bread types and of raw pasta products

\begin{tabular}{|c|c|c|c|c|c|c|c|c|c|c|}
\hline & $\operatorname{Mg}(\%)$ & $\mathrm{P}(\%)$ & $\mathrm{Ca}(\%)$ & $\mathrm{Cr}(\%)$ & $\operatorname{Mn}(\%)$ & $\mathrm{Fe}(\%)$ & $\mathrm{Cu}(\%)$ & $\mathrm{Zn}(\%)$ & $\mathrm{Se}(\%)$ & Mo (\%) \\
\hline Rye flour & $13 / 17$ & 27 & 3 & $6 / 9$ & $88 / 113$ & $23 / 10$ & 27 & $17 / 24$ & $2 / 2$ & 68 \\
\hline Rye whole flour & $24 / 31$ & 47 & 4 & $9 / 12$ & $104 / 133$ & $29 / 13$ & 39 & $27 / 38$ & $10 / 10$ & 134 \\
\hline Spelt flour & $9 / 11$ & 23 & 2 & $5 / 5$ & $40 / 51$ & $16 / 7$ & 22 & $14 / 19$ & $9 / 9$ & 64 \\
\hline Spelt whole flour & $29 / 38$ & 58 & 4 & $5 / 7$ & $126 / 161$ & $44 / 20$ & 50 & $35 / 48$ & $8 / 8$ & 94 \\
\hline Wheat flour (480) & $5 / 6$ & 13 & 2 & $3 / 4$ & $17 / 22$ & $8 / 4$ & 14 & $6 / 8$ & $49 / 49$ & 78 \\
\hline Wheat flour (700) & $9 / 11$ & 17 & 2 & $4 / 5$ & $29 / 37$ & $13 / 6$ & 18 & $11 / 15$ & $9 / 9$ & 121 \\
\hline Wheat whole flour & $31 / 41$ & 51 & 4 & $5 / 7$ & $147 / 187$ & $38 / 17$ & 44 & $32 / 44$ & $14 / 14$ & 162 \\
\hline Rye bread & $10 / 13$ & $23 / 23$ & $3 / 3$ & $5 / 7$ & $63 / 80$ & $17 / 8$ & $22 / 22$ & $14 / 20$ & $4 / 4$ & $71 / 71$ \\
\hline Rye bread with seeds & $12 / 16$ & $26 / 26$ & $3 / 3$ & $4 / 6$ & $52 / 66$ & $18 / 8$ & $29 / 29$ & $16 / 21$ & $7 / 7$ & $90 / 90$ \\
\hline Rye whole flour bread & $16 / 21$ & $33 / 33$ & $3 / 3$ & $4 / 6$ & $88 / 113$ & $25 / 11$ & $29 / 29$ & $18 / 25$ & $4 / 4$ & $66 / 66$ \\
\hline Spelt whole flour bread & $19 / 25$ & $44 / 44$ & $4 / 4$ & $11 / 16$ & $81 / 104$ & $36 / 16$ & $43 / 43$ & $22 / 30$ & $5 / 5$ & $60 / 60$ \\
\hline Wheat flour-pretzel sticks & $6 / 7$ & $16 / 16$ & $2 / 2$ & $4 / 6$ & $27 / 34$ & $11 / 5$ & $12 / 12$ & $7 / 10$ & $5 / 5$ & $46 / 46$ \\
\hline Wheat flour bread & $6 / 8$ & $17 / 17$ & $4 / 4$ & $7 / 10$ & $32 / 41$ & $14 / 6$ & $16 / 16$ & $8 / 11$ & $5 / 5$ & $45 / 45$ \\
\hline Wheat flour bread with seeds & $12 / 16$ & $26 / 26$ & $4 / 4$ & $6 / 8$ & $49 / 63$ & $18 / 8$ & $30 / 30$ & $14 / 19$ & $8 / 8$ & $65 / 65$ \\
\hline Wheat pasta & $8 / 10$ & $23 / 23$ & $2 / 2$ & $4 / 5$ & $29 / 38$ & $13 / 6$ & $30 / 30$ & $12 / 17$ & $23 / 23$ & $113 / 113$ \\
\hline Wheat pasta col. & $9 / 12$ & $22 / 22$ & $4 / 4$ & $16 / 22$ & $33 / 42$ & $22 / 10$ & $30 / 30$ & $10 / 13$ & $31 / 31$ & $125 / 125$ \\
\hline Whole wheat pasta & $19 / 25$ & $44 / 44$ & $3 / 3$ & $6 / 9$ & $88 / 113$ & $32 / 14$ & $49 / 49$ & $26 / 36$ & $11 / 11$ & $123 / 123$ \\
\hline
\end{tabular}

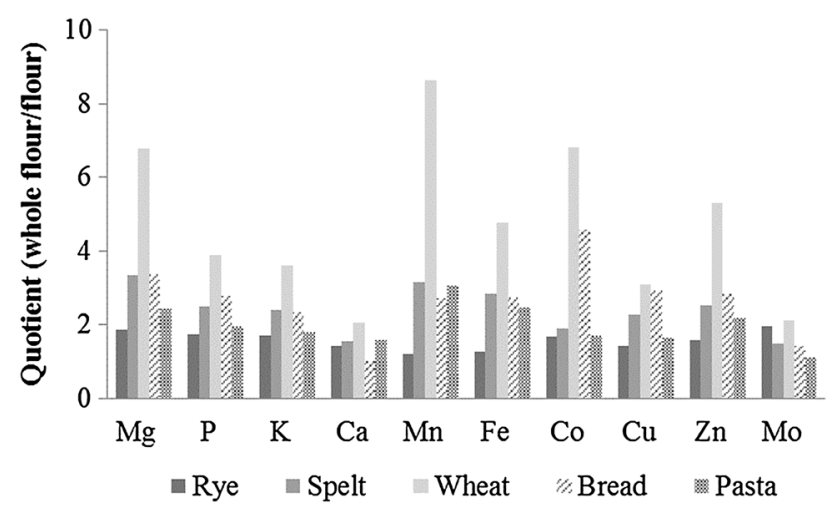

Fig. 1 Quotient whole flour/flour for rye, spelt, wheat, bread, and pasta

on the flour used for production, although milk and milk products would be a more efficient calcium source.

\section{$\mathrm{Mn}, \mathrm{Fe}$, and Zn}

Manganese concentrations show high variations between whole flour and flour samples, except for rye. Rye flour samples are also rich in manganese and, therefore, very similar to whole flour samples. Overall concentrations for grains and flours range between 2.1 and $42 \mathrm{mg} / \mathrm{kg}$. Several research groups have reported manganese concentrations mainly in wheat samples with concentrations between 8 and $87 \mathrm{mg} / \mathrm{kg}$ [16-24]. For bread and pasta, concentrations between 5.5 and $42 \mathrm{mg} / \mathrm{kg}$ could be observed with rye whole flour bread showing the highest manganese concentrations. Both white flour and whole flour products are suitable to meet the daily requirement. Between 86 and $310 \mathrm{~g}$ of bread are enough to meet the recommended uptake.

Mean iron values are very similar to mean manganese values with an overall range between 3.1 and $42 \mathrm{mg} / \mathrm{kg}$ for grains and flours and between 7.6 and $65 \mathrm{mg} / \mathrm{kg}$ for bread and pasta samples. The literature is mainly available for wheat samples and reports concentrations between 13 and $103 \mathrm{mg} / \mathrm{kg}$ [16-22, 24, 25]. To meet the daily requirement, meat is known to be the most efficient iron source which means that especially vegetarians are in need of other iron suppliers. $100 \mathrm{~g}$ of spelt whole flour bread, for example, can provide up to $36 \%$ of the daily requirement for men and up to $16 \%$ for women in the age group $31-50$ years providing all iron is bioavailable.

The overall range for zinc ranges from 3.8 to $50 \mathrm{mg} /$ $\mathrm{kg}$ in grains and flours, which is similar to $7.2-48 \mathrm{mg} /$ $\mathrm{kg}$ found in bread and pasta products. Like for several other elements, zinc concentrations are higher in whole flour than in white flour. Published zinc concentrations in grains range from $9.4 \mathrm{mg} / \mathrm{kg}$ up to $133 \mathrm{mg} / \mathrm{kg}$, with most values below $50 \mathrm{mg} / \mathrm{kg}$ [16-27]. Zinc is one of the most important trace elements, which makes an adequate supply mandatory. Main zinc suppliers are on the one hand the animal products meat and cheese and on the other hand grains and their products. Approximately $330-450 \mathrm{~g}$ of spelt whole flour bread would be enough to meet the daily requirement. 


\section{$\mathrm{B}, \mathrm{Co}, \mathrm{Ni}, \mathrm{Cu}, \mathrm{Se}$, and $\mathrm{Mo}$}

Boron concentrations range from 0.090 to $1.1 \mathrm{mg} / \mathrm{kg}$ in all investigated grain and flour samples. The obtained results are in good agreement with $0.43-1.0 \mathrm{mg} / \mathrm{kg}$ obtained for wheat samples in different Argentinean regions [17] and $0.7 \mathrm{mg} / \mathrm{kg}$ reported for spelt [18]. For bread and pasta samples, values between 0.16 and $2.2 \mathrm{mg} / \mathrm{kg}$ could be observed. Higher boron concentrations occur in various bread samples with sesame, sunflowers, or walnuts added. All 15 bread samples with sesame, sunflower, or walnuts added show a mean value of $1.5 \pm 0.4 \mathrm{mg} / \mathrm{kg}$, whereas all other bread samples $(n=39)$ show a mean value of $0.52 \pm 0.28 \mathrm{mg} / \mathrm{kg}$. This is not surprising as sunflowers and walnuts have a mean concentration of $11 \pm 2 \mathrm{mg} / \mathrm{kg}$ boron as internal studies have shown.

Most grain and flour samples as well as bread and pasta samples show cobalt concentrations above the limit of detection but do not exceed $0.047 \mathrm{mg} / \mathrm{kg}$ and are, therefore, in good agreement with most cereal literature values with a range between 0.004 and $0.14 \mathrm{mg} / \mathrm{kg}[16,17,19$, 21-23].

Obtained nickel concentrations range from 0.018 to $0.91 \mathrm{mg} / \mathrm{kg}$ with many concentrations below $0.1 \mathrm{mg} / \mathrm{kg}$. Only four spelt whole flour bread samples show concentrations between 2.0 and $2.6 \mathrm{mg} / \mathrm{kg}$. In the literature, flour and grain values up to $6.2 \mathrm{mg} / \mathrm{kg}$ are reported [27], but most concentrations are less than $1 \mathrm{mg} / \mathrm{kg}[16,17,21$, 22, 24, 26].

Compared to other elements, copper concentrations are within a narrow range from 1.0 to $8.1 \mathrm{mg} / \mathrm{kg}$. Our findings are again in good agreement with reported cereal literature values between 1.8 and $11 \mathrm{mg} / \mathrm{kg}$ [16-24, 26, 27]. Despite several vegetables and chocolate, grains are helpful to meet the daily copper requirement. $100 \mathrm{~g}$ of uncooked whole wheat pasta can supply up to $50 \%$ of the daily need.

Overall selenium values range for grain and flour samples between the limit of detection and $0.26 \mathrm{mg} / \mathrm{kg}$ and for bread and pasta samples between 0.011 and $0.24 \mathrm{mg} / \mathrm{kg}$. Literature reports values from $0.0096 \mathrm{mg} / \mathrm{kg}$ up to $0.5 \mathrm{mg} / \mathrm{kg}$ for grains and flours $[19,22,23,28,29]$. Selenium shows great variations within the investigated groups, but does not show a tendency towards higher concentrations in whole flour. $100 \mathrm{~g}$ of uncooked pasta provide up to $30 \%$ and $100 \mathrm{~g}$ of bread up to $8 \%$ of the daily requirement.

Molybdenum concentrations are in good agreement with published literature. Determined concentrations range from 0.17 to $1.6 \mathrm{mg} / \mathrm{kg}$ for grains and flours, whereas literature reports concentrations of $0.42,0.7$, and $0.23-0.58 \mathrm{mg} / \mathrm{kg}$ $[17,18,22]$. Depending on the bread composition between 150 and $250 \mathrm{~g}$ are necessary to meet the daily requirement, whereas less than $100 \mathrm{~g}$ of uncooked pasta are also suitable to meet the daily need.

\section{$\mathrm{Al}, \mathrm{V}, \mathrm{Cr}, \mathrm{As}, \mathrm{Rb}, \mathrm{Sr}, \mathrm{Cd}, \mathrm{Sb}, \mathrm{Ba}, \mathrm{Hg}, \mathrm{Pb}$, and U}

Aluminium concentrations for grains and flours are between 0.45 and $9.7 \mathrm{mg} / \mathrm{kg}$ and in good agreement with literature values such as $1.33-4.74,4$, and $5 \mathrm{mg} / \mathrm{kg}$ reported by Vrček and Vinković Vrček [22]; Podio et al. [17] and Ekholm et al. [21], respectively. For bread and pasta samples, most concentrations are below $5 \mathrm{mg} / \mathrm{kg}$, but also a value of $70 \mathrm{mg} /$ $\mathrm{kg}$ for coloured pasta was observed. This high value is most likely related to the added spinach powder. In general, aluminium concentrations do not show great differences between the investigated grain types and are, furthermore, typical for foodstuff. Seen alone, they are not likely to cause health problems, but contribute to the general aluminium uptake.

Vanadium concentrations are very low and range from the limit of detection up to $0.021 \mathrm{mg} / \mathrm{kg}$ for grain and flour samples and up to $0.093 \mathrm{mg} / \mathrm{kg}$ for bread and pasta samples. Vrček and Vinković Vrček [22] reported with $0.002-0.012 \mathrm{mg} / \mathrm{kg}$ in wheat flour very similar concentrations.

Chromium does not exceed $0.047 \mathrm{mg} / \mathrm{kg}$ for grains and flour and $0.20 \mathrm{mg} / \mathrm{kg}$ for bread and pasta samples and is, therefore, compared to grain literature concentrations, which range from 0.021 and $0.799 \mathrm{mg} / \mathrm{kg}$, rather low [16, 22, 24, 26, 27]. The highest concentrations with 0.20 and $0.17 \mathrm{mg} /$ $\mathrm{kg}$ were found in green and orange pasta samples.

Most arsenic concentrations are below or around the limit of detection with $0.006 \mathrm{mg} / \mathrm{kg}$. Only four spelt whole flour samples and with $0.032 \mathrm{mg} / \mathrm{kg}$ one coloured pasta sample show higher concentrations. Reported literature concentrations are between 0.02 and $0.086 \mathrm{mg} / \mathrm{kg}$ and higher than the concentrations found in this study [19, 23, 26]. Only Vrček and Vinković Vrček [22] reported similar low values with a concentration range for wheat flour from 0.0002 to $0.0028 \mathrm{mg} / \mathrm{kg}$. Arsenic concentrations found in wheat, spelt, and rye are low, especially when compared to rice, and with that not likely to be of any health concerns. Cubadda et al. [30] reported ten times higher concentrations for inorganic arsenic in rice than in wheat flour.

Rubidium shows large variations from one specimen to another, with an overall range between 0.54 and $30 \mathrm{mg} / \mathrm{kg}$ for grain and flour samples and 0.79 and $6.0 \mathrm{mg} / \mathrm{kg}$ for bread and pasta samples. Only few literature is available. Reported concentrations for grains and flours are $0.2,1.1$, and $1.7 \mathrm{mg} /$ $\mathrm{kg}$ by Podio et al. [17]; Suchowilska et al. [18] and Bermudez et al. [16], respectively.

Obtained strontium concentrations for grains and flours with a range from $0.30 \mathrm{mg} / \mathrm{kg}$ up to $1.9 \mathrm{mg} / \mathrm{kg}$ are rather low compared to 2.8 and $3.6 \mathrm{mg} / \mathrm{kg}$, reported by Podio et al. [17] and Suchowilska et al. [18]. Only Vrček and Vinković Vrček [22] reported lower values for wheat flour with a range between 0.0021 and $0.0034 \mathrm{mg} / \mathrm{kg}$. For bread 
and pasta samples, higher concentrations with an overall range from 0.50 to $4.8 \mathrm{mg} / \mathrm{kg}$ could be observed.

The European Commission established a maximum value for cadmium concentrations in grains. The concentration is set at $0.1 \mathrm{mg} / \mathrm{kg}$ wet mass for grains in general and $0.2 \mathrm{mg} / \mathrm{kg}$ wet mass for wheat in particular [31]. Even the highest observed concentration in grains and flour samples is with $0.046 \mathrm{mg} / \mathrm{kg}$ wet mass far below the given maximum. Although not regulated by the European Commission, most bread and pasta samples show concentrations below $0.050 \mathrm{mg} / \mathrm{kg}$ wet mass with the exception of again four whole spelt flour bread with concentrations up to $0.067 \mathrm{mg} / \mathrm{kg}$ wet mass. Reported literature concentrations range from $0.006 \mathrm{mg} / \mathrm{kg}$ up to $0.179 \mathrm{mg} / \mathrm{kg}[16$, $17,21,22,24,32,33]$. The highest concentrations from 0.428 to $0.897 \mathrm{mg} / \mathrm{kg}$ were found for wheat grown on soil amended with domestic sewage sludge [27].

All investigated antimony concentrations are below or only slightly above the limit of detection, but do not exceed $0.004 \mathrm{mg} / \mathrm{kg}$. The literature for antimony in grains is scarce, and only Bermudez et al. [16] reported $0.008 \mathrm{mg} / \mathrm{kg}$ for wheat.

With barium concentrations ranging from $0.34 \mathrm{mg} / \mathrm{kg}$ up to $6.3 \mathrm{mg} / \mathrm{kg}$, obtained values are rather high compared to other foodstuff, but in good agreement with literature values ranging between 3.5 and $9 \mathrm{mg} / \mathrm{kg}$ [16-18].

Most mercury concentrations are below $0.002 \mathrm{mg} / \mathrm{kg}$. Only some grain and flour samples show higher concentrations, but do not exceed $0.010 \mathrm{mg} / \mathrm{kg}$. Huang et al. [26] reported values between 0.003 and $0.006 \mathrm{mg} / \mathrm{kg}$.

In the case of lead, the European Commission also established a maximum allowed concentration of $0.02 \mathrm{mg} /$ $\mathrm{kg}$ wet mass in grains [34]. Regarding the fact that all investigated grain and flour samples are below $0.012 \mathrm{mg} /$ $\mathrm{kg}$ wet mass, no harm due to lead concentrations in Austrian grains is likely. This is also true for bread and pasta samples with lead concentrations below $0.011 \mathrm{mg} / \mathrm{kg}$ wet mass. Only one coloured pasta sample shows with $0.050 \mathrm{mg} / \mathrm{kg}$ wet mass a higher concentration. This could be caused by the use of spinach as colouring agent. In contrast to these results, some concentrations reported in the literature are well above the limit given by the European Commission. Literature data range between 0.002 and $1.6 \mathrm{mg} / \mathrm{kg}[16,17,21,22,24,26,32,33]$. The highest concentrations with $19.9-22.6 \mathrm{mg} / \mathrm{kg}$ were reported for wheat growing on soil amended with domestic sewage sludge [27].

All grain and flour uranium concentrations do not exceed the limit of detection of $0.001 \mathrm{mg} / \mathrm{kg}$. For bread and pasta samples, some concentrations are above this limit but with a highest observed concentration of $0.003 \mathrm{mg} / \mathrm{kg}$ also quite low.

\section{Elemental comparison whole flour-white flour}

As shown in Fig. 1, whole flour is compared to the corresponding white flour richer in the essential elements magnesium, phosphorus, potassium, calcium, manganese, iron, cobalt, copper, zinc, and molybdenum. This not surprising, as with every sieving step, bran, which is very rich in essential elements, is removed from the flour.

The quotient between rye whole flour and rye flour for essential elements is, with values below two, the smallest. That can be explained by the higher flour-type number (more bran left) and, therefore, the smaller difference between element concentrations in the whole flour and flour. For rye flour, flour-type numbers around 1000 are typically on the Austrian market. Boron, sulfur, chromium, nickel, and selenium show with quotients of approximately 1.2, 1.6, 1.4, 2, and 4 , respectively also higher concentrations in rye whole flour than in rye flour. Aluminium concentrations are with a quotient of 0.3 considerably lower in rye whole flour than in rye flour. For all other elements, no significant difference between rye whole flour and rye flour could be observed.

For the essential elements in spelt flour, quotients between 1.5 (sodium, calcium, and molybdenum) and 3 (manganese) were found (see Fig. 1). Higher concentrations in spelt whole flour than in spelt flour are also true for the elements boron (3), aluminium (2), vanadium (2), chromium (1.3), nickel (3), rubidium (2), strontium (1.9), cadmium (1.6), antimony (2), and barium (3). Sulfur, selenium, mercury, lead, and uranium are not significantly influenced by the flour type.

Wheat shows the highest quotients between element concentrations in whole flour and flour, with values up to 8.6 for manganese (see Fig. 1) in agreement with the flour-type number (in this case 480). That is why, the replacement of $125 \mathrm{~g}$ in $1 \mathrm{~kg}$ wheat flour with wheat whole flour can double the manganese concentration. For wheat flour, all elements show higher concentrations in whole flour samples than in white flour samples with the exception of aluminium, vanadium, selenium, mercury, lead, and uranium which do not show a significant difference. Additional to manganese also boron (4), sodium (2), magnesium (7), phosphorus (4), potassium (4), calcium (2), iron (5), cobalt (7), copper (3), zinc (5), rubidium (4), molybdenum (2), and barium (5) show quotients above 2 . However, the heavy metals nickel and strontium are, by a factor of 8 and 3 , respectively, also higher in wheat whole flour.

In general, for the essential elements, pasta samples, with a quotient up to 3 (manganese), show a larger difference between whole flour and flour products than bread samples. This can be explained by the lower water content in uncooked pasta than in bread (see Table 1), and therefore, the difference is more apparent. Nevertheless, whole flour bread is richer in elements than white flour bread as the following quotients demonstrate: boron (1.4), magnesium 
(1.7), phosphorus (1.5), potassium (1.4), vanadium (2), manganese (1.5), iron (1.5), cobalt (1.4), copper (1.4), zinc (1.3), and rubidium (1.7). However, also heavy metals like nickel, strontium, antimony, and lead, with quotients between 1 and 2 , tend to be higher in whole flour bread compared to white flour bread.

For pasta elements like magnesium (2), aluminium (7), phosphorus (2), vanadium (4.0), manganese (3), iron (3), zinc (2), arsenic (2), rubidium (3), strontium (2), and barium (2) show at least twice as high concentrations in whole flour pasta than in flour pasta.

In addition, element concentrations can be affected through contamination during milling/processing. Mainly, the concentrations of aluminium and chromium are affected, which are on average approximately twice as high in flours than in grains. Nickel, strontium, cadmium, and lead concentrations can also be affected.

\section{Conclusion}

Coloured pasta samples show higher standard deviations than their uncoloured counterparts because of the addition of different powders to change the noodle colour. In addition, on average, they contain higher amounts of aluminium, chromium, and vanadium. For grains and whole flours with their corresponding end products, it is demonstrated that they are in most cases far more suitable to meet the daily requirement of various elements than the so-called white flours with their products. In addition, bread types with seeds can further improve the daily elemental uptake compared to similar bread varieties without seeds. The amount of improvement is strongly dependent on the seed, seed amount, and flour type used, but can reach a factor of 3. Furthermore, all samples, independent from the type, showed no contamination due to heavy metals. To sum it up, the consumption of whole flour products, like whole flour bread or pasta, can increase the element uptake significantly and is, therefore, highly recommended.

Acknowledgements Open access funding provided by University of Graz.

\section{Compliance with ethical standards}

Conflict of interest The authors declare that they have no conflict of interest.

Compliance with ethics requirements This article does not contain any studies with human or animal subjects performed by any of the authors.

Open Access This article is distributed under the terms of the Creative Commons Attribution 4.0 International License (http://creat ivecommons.org/licenses/by/4.0/), which permits unrestricted use, distribution, and reproduction in any medium, provided you give appropriate credit to the original author(s) and the source, provide a link to the Creative Commons license, and indicate if changes were made.

\section{References}

1. Statistik Austria (2016) Versorgungsbilanz für Getreide 2014/15. http://www.statistik.at/web_de/statistiken/wirtschaft/land_und_ forstwirtschaft/preise_bilanzen/versorgungsbilanzen/index.html. (in German)

2. Agrar Markt Austria (2015) Getreide Bilanz Wirtschaftsjahr 2013/14-EU 28. https://www.ama.at/getattachment/e76ef 321-318f-4bd7-9844-7fe89109ad64/Marktbericht_Getreide_ Oelsaaten_02_2015.pdf. (in German)

3. The European Parliament and the Council of the European Union (2013) Regulation no. 1308/2013 of the European Parliament and of the council establishing a common organisation of the markets in agricultural products and repealing Council Regulations (EEC) No 922/72, (EEC) No 234/79, (EC) No $1037 / 2001$ and (EC) No 1234/2007. Off J Eur Union L347/671L347/854. https://eur-lex.europa.eu/eli/reg/2013/1308/oj

4. Sette S, D'Addezio L, Piccinelli R, Hopkins S, Le Donne C, Ferrari M, Mistura L, Turrini A (2017) Intakes of whole grain in an Italian sample of children, adolescents and adults. Eur J Nutr 56(2):521-533

5. Bellisle F, Hébel P, Colin J, Reyé B, Hopkins S (2014) Consumption of whole grains in French children, adolescents and adults. Br J Nutr 112(10):1674-1684

6. Swedish National Food Agency (2015) Swedish dietary guidelines. Rapport 5-2015

7. Arvola A, Lähteenmäki L, Dean M, Vassallo M, Winkelmann M, Claupein E, Saba A, Shepherd R (2007) Consumers' beliefs about whole and refined grain products in the UK, Italy and Finland. J Cereal Sci 46(3):197-206

8. Ávila B, Braganca G, Rockenbach R, Alves G, Monks J, Gularte M, Elias M (2017) Physical and sensory characteristics of cake prepared with six whole-grain flours. J Food Meas Charact 11(3):1486-1492

9. Whitney K, Simsek S (2017) Reduced gelatinization, hydrolysis, and digestibility in whole wheat bread in comparison to white bread. Cereal Chem 94(6):991-1000

10. Vignola M, Bustos M, Pérez G (2018) Comparison of quality attributes of refined and whole wheat extruded pasta. LWT Food Sci Technol 89:329-335

11. Albergamo A, Bua G, Rotondo A, Bartolomeo G, Annuario G, Costa R, Dugo G (2018) Transfer of major and trace elements along the "farm-to-fork" chain of different whole grain products. Food Compos Anal 66:212-220

12. Valli V, Taccari A, Di Nunzio M, Danesi F, Bordoni A (2018) Health benefits of ancient grains. Comparison among bread made with ancient, heritage and modern grain flours in human cultured cells. Food Res Int (Ott Ont) 107:206-215

13. Punshon T, Jackson B (2018) Essential micronutrient and toxic trace element concentrations in gluten containing and gluten-free foods. Food Chem 252:258-264

14. Food and Nutrition Board, Institute of Medicine (1997) Dietary reference intakes for calcium, phosphorous, magnesium, vitamin D, and fluoride. National Academy Press, Washington, DC

15. Food and Nutrition Board (2001) Dietary reference intakes for vitamin $\mathrm{A}$, vitamin $\mathrm{K}$, arsenic, boron, chromium, copper, iodine, iron, manganese, molybdenum, nickel, silicon, vanadium, and zinc. The National Academies Press, Washington, DC 
16. Bermudez G, Jasan R, Plá R, Pignata M (2011) Heavy metal and trace element concentrations in wheat grains: assessment of potential non-carcinogenic health hazard through their consumption. J Hazard Mater 193:264-271

17. Podio N, Baroni M, Badini R, Inga M, Ostera H, Cagnoni M, Gautier E, García P, Hoogewerff J, Wunderlin D (2013) Elemental and isotopic fingerprint of Argentinean wheat. Matching soil, water, and crop composition to differentiate provenance. J Agric Food Chem 61(16):3763-3773

18. Suchowilska E, Wiwart M, Kandler W, Krska R (2012) A comparison of macro- and microelement concentrations in the whole grain of four Triticum species. Plant Soil Environ 58(3):141-147

19. Ahmed Y, Landsberger S, O'Kelly D, Braisted J, Gabdo H, Ewa I, Umar I, Funtua I (2010) Compton suppression method and epithermal NAA in the determination of nutrients and heavy metals in Nigerian food and beverages. Appl Radiat Isot 68(10):1909-1914

20. Araujo R, Dias FdeS, Macedo S, Santos Walter NL, dos Ferreira $S$ (2007) Method development for the determination of manganese in wheat flour by slurry sampling flame atomic absorption spectrometry. Food Chem 101(1):397-400

21. Ekholm P, Reinivuo H, Mattila P, Pakkala H, Koponen J, Happonen A, Hellström J, Ovaskainen M (2007) Changes in the mineral and trace element contents of cereals, fruits and vegetables in Finland. J Food Compost Anal 20(6):487-495

22. Vrček V, Vinković Vrček I (2012) Metals in organic and conventional wheat flours determined by an optimised and validated ICP-MS method. Int J Food Sci Technol 47(8):1777-1783

23. Adomako E, Williams P, Deacon C, Meharg A (2011) Inorganic arsenic and trace elements in Ghanaian grain staples. Environ Pollut 159(10):2435-2442

24. Akinyele I, Shokunbi O (2015) Concentrations of Mn, Fe, Cu, Zn, $\mathrm{Cr}, \mathrm{Cd}, \mathrm{Pb}, \mathrm{Ni}$ in selected Nigerian tubers, legumes and cereals and estimates of the adult daily intakes. Food Chem 173:702-708

25. Morgounov A, Gómez-Becerra H, Abugalieva A, Dzhunusova M, Yessimbekova M, Muminjanov H, Zelenskiy Y, Ozturk L, Cakmak I (2007) Iron and zinc grain density in common wheat grown in Central Asia. Euphytica 155(1-2):193-203
26. Huang M, Zhou S, Sun B, Zhao Q (2008) Heavy metals in wheat grain: assessment of potential health risk for inhabitants in Kunshan, China. Sci Total Environ 405(1-3):54-61

27. Jamali M, Kazi T, Arain M, Afridi H, Jalbani N, Kandhro G, Shah A, Baig J (2009) Heavy metal accumulation in different varieties of wheat (Triticum aestivum L.) grown in soil amended with domestic sewage sludge. J Hazard Mater 164(2-3):1386-1391

28. Hahn M, Kuennen R, Caruso J, Fricke F (1981) Determination of trace amounts of selenium in corn, lettuce, potatoes, soybeans, and wheat by hydride generation/condensation and flame atomic absorption spectrometry. J Agric Food Chem 29:732-796

29. Klapec T, Mandić M, Grgić J, Primorac L, Perl A, Krstanović V (2004) Selenium in selected foods grown or purchased in eastern Croatia. Food Chem 85(3):445-452

30. Cubadda F, D'Amato M, Aureli F, Raggi A, Mantovani A (2016) Dietary exposure of the Italian population to inorganic arsenic: the 2012-2014 total diet study. Food Chem Toxicol 98:148-158

31. The European Commission (2014) Commission Regulation (EU) No 488/2014 amending Regulation (EC) No 1881/2006 as regards maximum levels of cadmium in foodstuffs. Off J Eur Union L138/75-L138/79. https://eur-lex.europa.eu/legal-content/ EN/TXT/?uri=celex:32014R0488

32. Shimbo $S$, Zhang Z, Watanabe T, Nakatsuka H, Matsuda-Inoguchi N, Higashikawa K, Ikeda M (2001) Cadmium and lead contents in rice and other cereal products in Japan in 1998-2000. Sci Total Environ 281(1-3):165-175

33. Wolnik K, Fricke F, Capar F, Braude G, Meyer M, Satzger R, Bonnin E (1983) Elements in major raw agricultural crops in the United States. 1. Cadmium and lead in lettuce, peanuts, potatoes, soybeans, sweet corn, and wheat. J Agric Food Chem 31:1240-1244

34. The Commission of the European Communities (2006) Commission Regulation (EC) No 1881/2006 setting maximum levels for certain contaminants in foodstuffs. Off $\mathbf{J}$ Eur Union L364/5-L364/24. https://eur-lex.europa.eu/legal-content/EN/ ALL/?uri=celex\%3A32006R1881 